\title{
Investigation of Hot Rolling Influence on the Explosive-Welded Clad Plate
}

\author{
Guanghui ZHAO, Qingxue HUANG*, Cunlong ZHOU, Xiaorong YANG, Guangming LIU, \\ Lifeng MA
}

\begin{abstract}
Shanxi Provincial Key Laboratory of Metallurgical Device Design Theory and Technology, Taiyuan University of Science and Technology, Taiyuan 030024, Shanxi, China
\end{abstract}

cross $^{\text {ref }}$ http://dx.doi.org/10.5755/j01.ms.22.4.12409

Received 01 June 2015; accepted 27 July 2015

\begin{abstract}
The microstructure, the shear strength and tensile strength of stainless steel explosive-welded clad plate at different rolling reduction were studied. The mechanical properties of the explosive-welded and explosive-rolled clad plates were experimentally measured. Simultaneously, the microstructures of the clad plate were investigated by the ultra deep microscope and the tensile fracture surface were observed by the scan electron microscope (SEM). It was observed that the tensile strength has been increased considerably, whereas the elongation percentage has been reduced with the increase of hot rolling reduction. In the tensile shear test, the bond strength is higher than the strength of the ferritic stainless steel layer and meets the relevant known standard criterion. Microstructural evaluations showed that the grain of the stainless steel and steel refined with the increase of thickness reduction. Examination of the tensile fracture surfaces reveal that, after hot rolling, the fracture in the low alloy steel and ferritic stainless steel clad plates is of the ductile type.

Keywords: rolling reduction, clad plate, mechanical properties, microstructure, fractography.
\end{abstract}

\section{INTRODUCTION}

With the increase of crude oil containing sulfur and acid content, refining units in some containers require more equipment corrosion resistance. Therefore the selection of materials increasingly higher, generally carbon steel and low alloy steel has been unable to meet the requirements, and a higher level of material, such as stainless steel have been used. However, all stainless steel has high one-time investment. To reduce investment costs, while meeting the requirements of the corrosion process media, a lot of equipment in refining units is the use of composite board material. Clad plate combines the advantages of both base material and clad material. Therefore, it not only have the structural rigidity and structural strength of the base material, but also the unique corrosion and wear-resistant characteristics of the clad material. Simultaneously, using the clad metal greatly reduces the weight of the equipment and cost of the equipment. With the size structure of decreasing and reducing waste in the use of aluminum, titanium, copper, nickel, steel and other precious metal material, it is possible to promote common development of social and economic benefits.

At present, there are three main bonding processes for stainless steel clad plate, namely, explosive bonding $[1-4]$, rolling bonding $[5,6]$ and explosive-rolling bonding. Explosive bonding is a solid-state metals joining process in which an explosive force can realize a metallurgical bond between two metal components. However, explosion bonding is relatively expensive and the available size of clad plate is often restricted in this bonding process [7]. What's more, the metallurgical

\footnotetext{
* Corresponding author. Tel.: +8613803465596.

E-mail address: hqx@tyust.edu.cn (Q.X. Huang)
}

interface of explosive bonded plate have some defects, which may be melting cavity or mixed crystal. These defects seriously affect the using of explosive bonded plate, especially when it is fabricated the high temperature and high pressure equipment used in the pressure vessels.

To solve these problems, a hot roll bonding process after explosive bonding has been used, and satisfactory bonding results have been obtained through an optimum rolling parameters. Jiang Haitao et al. [7] studied microstructure and mechanical properties of titanium explosive clad plate after asymmetric rolling. Explosive-rolled process was used by Mamalis et al. [8] to fabricate aluminum/copper bimetal and also make nickel/titanium "shape-memory" bimetallic strips [9]. M. Asemabadi and M. Sedighi have studied the cold rolling influence on the explosive-welded $\mathrm{Al} / \mathrm{Cu}$ bimetal [10].

Rolling reduction has great effects on the mechanical property and the microstructure of stainless steel explosive-welded clad plate. Therefore, this paper mainly studied the influence of the hot rolling reduction on the mechanical properties and microstructure of explosivewelded low alloy steel/ferritic stainless steel clad plate. In this paper, the interfacial morphology and mechanical property of stainless steel explosive clad plate after different rolling reduction were studied. The microstructures of the explosive-rolled clad plate were investigated by the Ultra deep microscope and the tensile fracture surface were observed by the scanning electron microscope (SEM).

\section{EXPERIMENTAL PROCEDURE}

The stainless steel explosive clad plate used in this study was manufactured by Taiyuan Taigang Clad Metal Materials Co. Ltd. A ferritic stainless steel (06Cr13) sheet and a low alloy steel (Q345R) plate were joined by explosive bonding process. 
Table 1. Chemical compositions and mechanical properties of ferritic stainless steel and low alloy steel materials used in this study

\begin{tabular}{|c|c|c|c|c|c|c|c|c|}
\hline \multirow{2}{*}{ Alloy } & \multicolumn{9}{|c|}{ Chemical composition, wt.\% } & \multicolumn{2}{c|}{ Mechanical properties, MPa } \\
\cline { 2 - 9 } & $\mathrm{C}$ & $\mathrm{Si}$ & $\mathrm{Mn}$ & $\mathrm{P}$ & $\mathrm{S}$ & $\mathrm{Cr}$ & Yield stress & Ultimate tensile strength \\
\hline 06Cr13 & 0.04 & 0.26 & 0.93 & 0.021 & 0.002 & 13.13 & 205 & 415 \\
\hline Q345R & 0.15 & 1.43 & 0.39 & 0.018 & 0.005 & - & 345 & 590 \\
\hline
\end{tabular}

The thickness of stainless steel explosive clad sheet was $3 \mathrm{~mm}$ (ferritic stainless steel sheet) $+14 \mathrm{~mm}$ (low alloy steel plate). Table 1 show the chemical composition and physical characteristics of the ferritic stainless steel and low alloy steel.

In order to investigate the effects of the rolling reduction on the mechanical properties of the explosively welded low alloy steel/ferritic stainless steel plates, samples with dimensions of $17 \times 80 \times 150 \mathrm{~mm}$ were cut parallel to the explosion direction. Then samples were hot rolled at thickness reductions equal to $15 \%, 30 \%, 40 \%$, $50 \%, 60 \%$ and $70 \%$ (Fig. 1), after incubated 25 minutes at $1250{ }^{\circ} \mathrm{C}$. The plates were air-cooled after hot rolling. There was at a at a constant speed of $12.0 \mathrm{rpm}$ between rolls with $320 \mathrm{~mm}$ diameter in the rolling processes.

In order to evaluate the effect of the rolling reduction on the tensile strength and tensile shear strength, the explosive-welded and explosive-rolled clad plates were prepared according to the Chinese Standard GB/T 6396-2008 [11], along the rolling direction. To measure the microstructure of the explosive-rolled samples with different rolling reductions, the samples normal to the rolling direction were cut with transverse cross section. The $4 \%$ nitric acid alcohol was used as an etchant to reveal interface microstructures. The microstructures were examined by the Ultra deep microscope. To study the tensile fracture type, the tensile fracture surface were observed by the scan electron microscope (SEM). It is important to confirm that all of the rolling direction and also the test sampling direction are consistent with the explosion direction of samples. Also the microstructure has been studied in transverse cross section of the samples (Fig. 1).

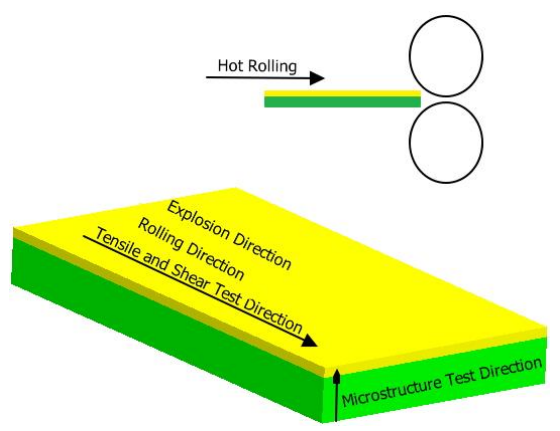

Fig. 1. Schematic view of hot rolling process and test sampling direction

\section{RESULTS AND DISCUSSION}

In order to observe the interface bonding of explosivewelded ferritic stainless steel clad plate, the samples parallel to the explosion direction were cut with transverse cross section. Then, it was investigated by the Ultra deep microscope. Fig. 2 shows an image of the interface of the explosive-welded ferritic stainless steel clad plate. As it can be observed, bonding had wavy morphology at the interface of the explosive-welded low alloy steel /ferritic stainless steel clad plate (Fig. 2 b).
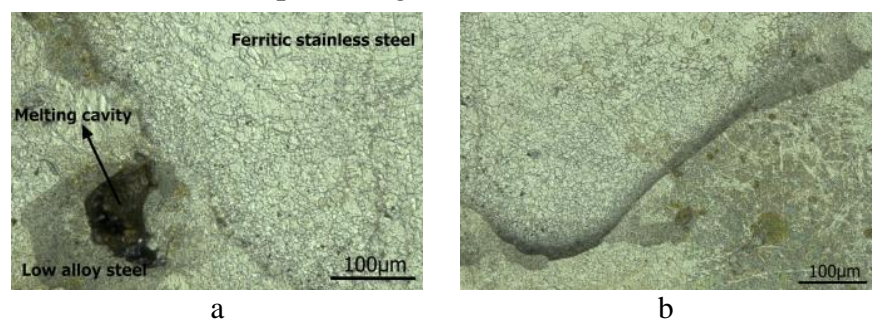

Fig. 2. The ultra deep microscopic figure of ferritic stainless steel and a low alloy steel clad plate before the hot rolling: $\mathrm{a}$ - having melting cavity; $\mathrm{b}$ - not having melting cavity

This means that wavy welding interface were formed in the explosive welding process. As a result of wavy interface, total interface area increased. In the explosive welding process, straight and wavy interfaces can be formed between explosively welded materials, however wavy interface is preferred due to better mechanical properties [1,12]. Because of the characteristic sharp transition between two materials, the interfaces were depicted. Two types of bond are generally encountered at the both wavy and straight forms of explosive welded materials; these are metal/metal and metal/solidified melt [13]. In this study, low alloy steel/ferritic stainless steel had metal/metal transition type and had melting and intermetallic zone (Fig. 2). In high explosive ratio, ejection between explosively welded materials will be formed. This cause to melting area in interface and also possible oxidation and dirty surface will not be exported to outside [1]. As with previous researches $[1,14]$, in this study, melting cavity or zone was been observed in the low alloy steel/ferritic stainless steel interface. On the other hands, it was mentioned that in the explosive welding, a hard and brittle intermetallic is formed and this intermetallic have an negative influence on the bonding quality and the mechanical properties [15]. In view of Fig. 2, it is clearly observed that intermetallic layer was formed between explosively welded materials and so, the influence of this layer was studied.

\subsection{Tensile strength}

For tensile test, Fig. 3 shows engineering stress-strain curves of samples by as fabricated and different hot rolling reductions. According to the Fig. 3, it can be seen that the tensile and yield strength increase significantly with the hot rolling reduction percentage increasing. Such as, the tensile strength has been increased from $429.9 \mathrm{MPa}$ to $509 \mathrm{MPa}$ when hot rolling reduction percentage reached $70 \%$. Fig. 4 shows hot rolling influence on the tensile strength and elongation of explosive-welded low alloy steel/ferritic stainless steel clad plate. It was observed that the tensile strength has been increased considerably, whereas the elongation percentage has been reduced with the increase of hot rolling reduction. 


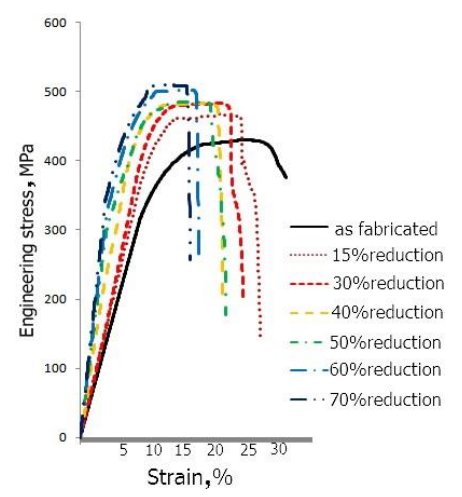

Fig. 3. Engineering stress-strain curves for low alloy steel/ferritic stainless steel clad plate by as fabricated and different hot rolling reductions

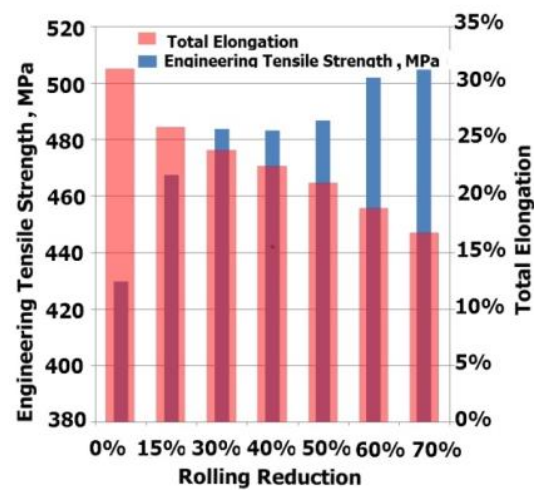

Fig. 4. The change of tensile strength and elongation of the samples by as fabricated and different hot rolling reductions

\subsection{Tensile shear strength}

In accordance with the Chinese standard GB/T 6396-2008 [11], tensile shear was conducted for the samples. If fracture occurs in the bond surface, it implies that the tensile shear strength of the bond interface is lower than the strength of the explosively welded materials. Observing all the tensile-shearing test samples (as fabricated and different hot rolling reductions), the fracture of the different hot rolling reductions has always occurred only in the ferritic stainless steel layer and no fracture has appeared at the joining interfaces except explosively welded sample. This indicates that the bond strength is stronger than that of the ferritic stainless steel layer, and it implies that all joins (except explosively welded sample) are safely according to the standard mentioned above. Because of the ferritic stainless steel layer was much thinner than the low alloy steel, it was easily broken than the low alloy steel. The treatment of the hot rolling may homogenize and densify microstructure, and further more improve the strength of the bond interface for the explosively welded low alloy steel/ferritic stainless steel plates. In the next section, the impact of hot-rolling on the microstructure was studied. In other people's research of the literature, no separation occurred at the joining interfaces. For example, Durgutlu et al. [16] have shown about that no separation occurred from the interface in stainless steel and copper multilayer plates. Also, M. Asemabadi and M. Sedighi [10] have reported that no separation occurred from the interface in aluminum and copper multilayer plates.

\subsection{Microstructural observation}

In Fig. 5, melting cavity or zone was not seen in the low alloy steel/ferritic stainless steel interface, that is to say, hot rolling eliminated melting cavity or zone at the interface of explosive welding clad plate. Removing pores is a two-step process [17]. The first step is the densification of pores using rolling to remove the overall configuration of the pores. Then, during the second step, complete removal is achieved by welding between the pore surfaces using thermal energy (hot rolling). Also, Fig. 5 showed the variation of diffusion layer's thickness and grain size in the low alloy steel/ferritic stainless interface after hot rolling for different reduction ratio. For $15 \%$ reduction ratio of hot rolling, the diffusion layer formed was thick (Fig. 5 a), but with when the reduction ratio was increased to $70 \%$ (Fig. $5 \mathrm{f}$ ), the thin diffusion layer was outlined. During hot rolling, diffusion layer was largely due to the plastic deformation, which would make diffusion layer extended along the rolling direction. So, the thickness of diffusion layer was decreased with the reduction of hot rolling. With the increase of the reduction ratio, the original wavy morphology on the bonding interface (Fig. 2 b) became flat.
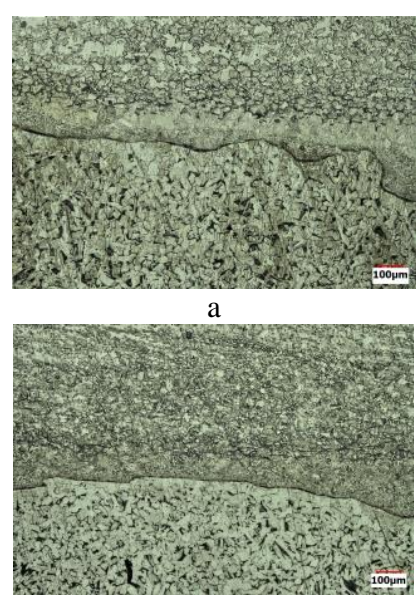

c

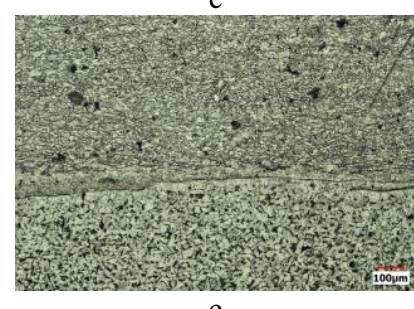

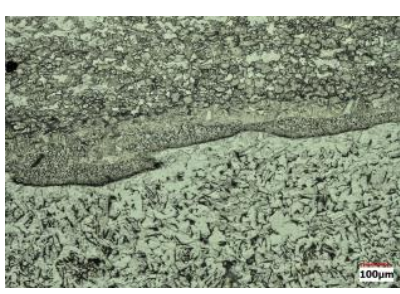

b

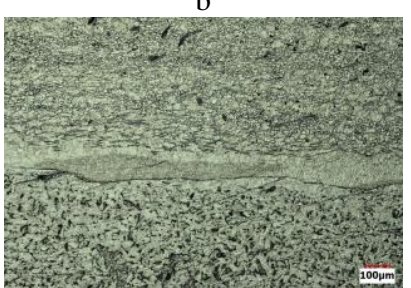

d

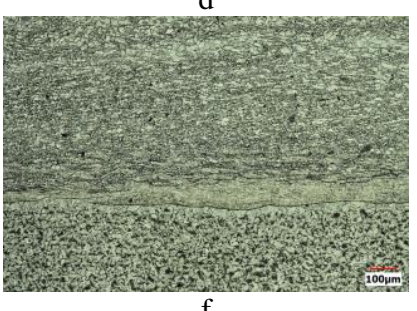

Fig. 5. The ultra deep microscopic figure of low alloy steel /ferritic stainless steel clad plate after hot rolling for: $\mathrm{a}-15 \%$ reduction; $\mathrm{b}-30 \%$ reduction; $\mathrm{c}-40 \%$ reduction; $\mathrm{d}-50 \%$ reduction; $\mathrm{e}-60 \%$ reduction; $\mathrm{f}-70 \%$ reduction

When reduction ratio increased to more than 50 percent, the kind of wave was gone, and then the bonding interface became straight. Also, similar studies [18] show that the original wavy morphology on the bonding interface became flat with the increase of the reduction ratio. 
In the hot rolling process, the plates were due to a plastic deformation, which would make grains extended along the rolling direction. Subjected to dynamic recrystallization, elongated grains become equiaxed grains. According to the Fig. 5, it can be observed that the elongated grains and equiaxed grains were present. The grain in size was decreased with the reduction ratio (Fig. 5). When reduction ratio increased to more than 50 percent, complete dynamic recrystallization occurred and the size of equiaxed grains is about $10 \mu \mathrm{m}$ (Fig. 5 d, e, f).

\subsection{Fractography}

To study the tensile fracture type, the tensile fracture surface were observed by the scan electron microscope (SEM). Fig. 6 shows the fracture surfaces of low alloy steel/ferritic stainless steel clad plate conducted by the tensile test. These pictures are low multiples picture of the SEM to observe the whole morphology. Except the ferritic stainless steel of explosive welded sample, all the metal of the samples are ductile fracture. The thickness of diffusion layer was decreased with the reduction of hot rolling, which agrees with the Ultra deep microscope observation. a

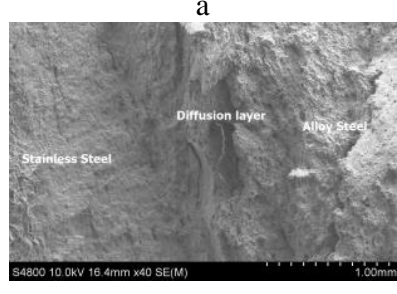

c
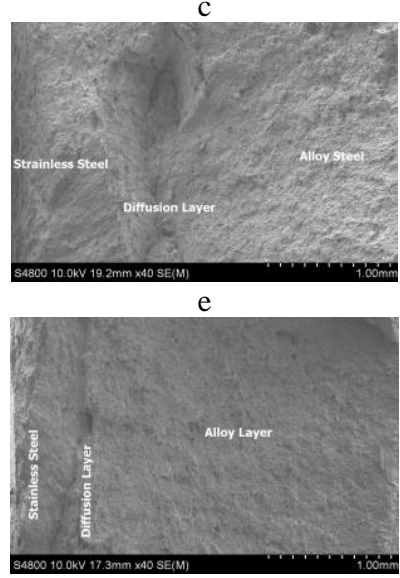

$\mathrm{g}$

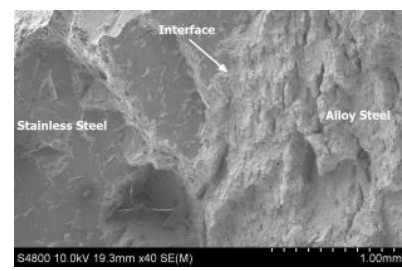

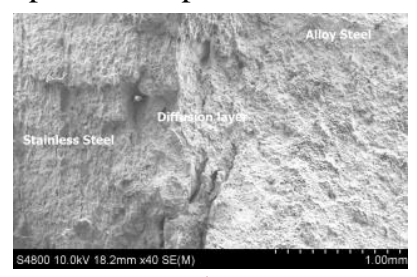

b

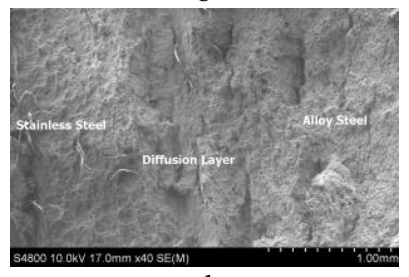

d

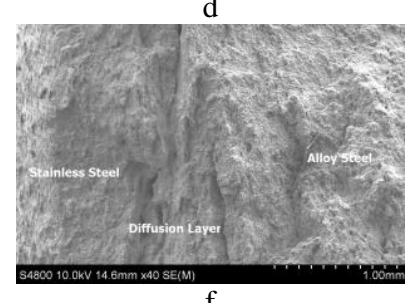

f

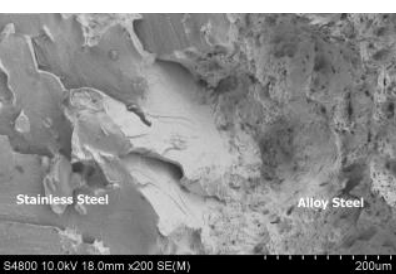

a

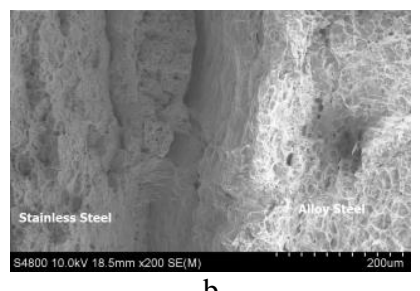

b
Fig. 7. The x200 facture surface of low alloy steel/ferritic stainless steel clad plate: $a-a$ fabricated; $b-60 \%$ reduction

These images indicate that ductile fracture of the explosive-rolled samples occurred with shear dimples in the tensile test. The treatment of the hot rolling may homogenize and densify microstructure, and further more improve the strength of the bond interface for the explosively welded low alloy steel/ferritic stainless steel plates. After hot rolling, the fracture in the low alloy steel and ferritic stainless steel clad plates is of the ductile type. Also, similar studies [8, 10, 19] reported that under plastic deformation and tension, shear band has been formed at the bond interface of clad plate, subjected to fragmentation intermetallic compounds formed at the joining interface. This causes to accelerate the nucleation and propagate of micro-crack, and subsequently causes to the reduction of ductility and fracture of the samples. The treatment of the hot rolling densified microstructure and reduced the melting and intermetallic zone of the explosive-welded low alloy steel/ferritic stainless steel clad plate, and further more improved the toughness strength of the bond interface for the explosively welded low alloy steel/ferritic stainless steel plates.

\section{CONCLUSIONS}

In this work, effect of hot rolling reduction on the mechanical properties, bond strength and microstructure of explosive-welded low alloy steel/ferritic stainless steel clad plate has been studied. The conclusions can be summarized as below:

1. At the interface of the explosive-welded low alloy steel/ferritic stainless steel clad plate, the bonding had wavy morphology and melting cavity or zone, after explosive welding.

2. The tensile strength has been increased considerably, whereas the elongation percentage has been reduced with the increase of hot rolling reduction.

3. The treatment of the hot rolling may homogenize and densify microstructure, and further more improve the strength of the bond interface for the explosively welded low alloy steel/ferritic stainless steel plates.

4. The grain of the stainless steel and steel refined with the increase of hot rolling reduction.

5. After hot rolling, the fracture in the low alloy steel and ferritic stainless steel plates is of the ductile type.

Fig. 6. The facture surface of low alloy steel/ferritic stainless steel clad plate: $\mathrm{a}-\mathrm{as}$ fabricated; $\mathrm{b}-15 \%$ reduction; $\mathrm{c}-30 \%$ reduction; $\mathrm{d}-40 \%$ reduction; $\mathrm{e}-50 \%$ reduction; $\mathrm{f}-60 \%$ reduction; $\mathrm{g}-70 \%$ reduction

To further study, Fig. 7 shows high multiples pictures of the SEM. The ferritic stainless steel of explosive welded sample is brittle fracture of rivers state (Fig. 7 a), the reason of which may be the influence of explosive welded. The others metal layer are ductile fracture.

\section{Acknowledgments}

This work was supported by the National Natural Science Foundation of China (Grant No. U1510131), and the National Key Technology Research and Development Program in 12th Five-year Plan of China(2012CB722801). 


\section{REFERENCES}

1. Fehim, F. Recent Developments in Explosive Welding Materials and Design 32 2011: pp. 1081-1081.

2. Manikandana, P., Hokamotob, K., $\quad$ Fujitac, M., Raghukandand, K., Tomoshige. R. Control of Energetic Conditions by Employing Interlayer of Different Thickness for Explosive Welding of Titanium/304 Stainless Steel Journal of Materials Processing Technology 195 2008: pp. $232-232$. http://dx.doi.org/10.1016/j.jmatprotec.2007.05.002

3. Akbari-Mousavi, S.A.A., Farhadi-Sartangi, $\mathbf{P}$. Exeprimental Investigation of Explosive Welding of CpTitanium/AISI 304 Stainless Steel Materials and Design 30 2009: pp. 459-459. http://dx.doi.org/10.1016/j.matdes.2008.06.016

4. Songa, J., Kostkaa, A., Veehmayerb, M. Hierarchical Microstructure of Explosive Joints: Example of Titanium to Steel Cladding Materials Science and Engineering A 528 2011: pp. 2641-2641. http://dx.doi.org/10.1016/j.msea.2010.11.092

5. Yan, J.C., Zhao, D.S., Wang, C.W. et al. Vacuum Hot Roll Bonding of Titanium Alloy and Stainless Steel Using a Nickel Interlayer Materials Science and Technology 25 2009: pp. 914-914.

6. Zhao, D.S., Yan, J.C., Wang, Y. et al. Relative Slipping of Interface of Titanium Alloy to Stainless Steel During Vacuum Hot Roll Bonding Materials Science and

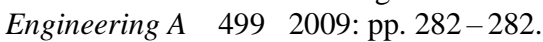

7. Jiang, H.T., Yan, X.Q., Liu, J.X., Duan, X.G., Zeng, S.W. Influence of Asymmetric Rolling Parameters on the Microstructure and Mechanical Properties of Titanium Explosive Clad Plate Rare Metal Materials and Engineering 43 (11) 2014: pp. 2631-2631.

8. Mamalis, A.G., $\quad$ Vaxevanidis, N.M., $\quad$ Szalay, A., Prohaszka. J. Fabrication of Aluminium/Copper Bimetallics by Explosive Cladding and Rolling Journal of Materials Processing Technology 44 1994: pp. 99-117.

9. Mamalis, A.G., $\quad$ Szalay, A., $\quad$ Vaxevanidis, N.M., Pantelis, D.I. Macroscopic and Microscopic Phenomena of Nickel/Titanium "Shape-Memory" Bimetallic Strips Fabricated by Explosive Cladding and Rolling Materials Science and Engineering A 188 1994: pp. 267-275.
10. Asemabadi, M., Sedighi, M., Honarpisheh, M. Investigation of Cold Rolling Influence on the Mechanical Properties of Explosive-Welded $\mathrm{Al} / \mathrm{Cu}$ Bimetal Materials $\begin{array}{lll}\text { Science and Engineering A } 558 & \text { 2012: pp. 144-149. }\end{array}$ http://dx.doi.org/10.1016/j.msea.2012.07.102

11. GB/T 6396-2008, Standard Test Methods for Stainless Steel Clad Plates, Sheets and Strips, 2008.

12. Durgutlu, A., Gulenc, B., Findik, F. Examination of Copper/Stainless Steel Joints Formed by Explosive Welding. Materials and Design 26 2005: pp. 497-507. http://dx.doi.org/10.1016/j.matdes.2004.07.021

13. Acarer, M., Demir, B. An Investigation of Mechanical and Metallurgical Properties of Explosive Welded Aluminum-Dual Phase Steel Materials Letters 62 2008: pp. $4158-4160$. http://dx.doi.org/10.1016/j.matlet.2008.05.060

14. Acarer, M., Gulenc, B., Findik, F. Investigation of Explosive Welding Parameters and Their Effects on Microhardness and Shear Strength Materials and Design 24 2003: pp. 659-664.

15. Durgutlu, A., Okuyucu, H., Gulenc, B. Investigation of Effect of the Stand-off Distance on Interface Characteristics of Explosively Welded Copper and Stainless Steel Materials and Design 29 2008: pp. 1480-1484.

16. Durgutlu, A., Gulenc, B., Findik, F. Examination of Copper/Stainless Steel Joints Formed by Explosive Welding Materials and Design 26 2005: pp. 497-507.

17. Wang, A., Thomson, P.F., Hodgson, P.D. A Study of Pore Closure and Welding in Hot Rolling Process Journal of Materials Processing Technology 60 1996: pp. 95-102.

18. Zheng, Y.M. Press Working of Explosive Welded Composite Material Metals Research on Iron and Steel 1999: pp. $33-34$.

19. Eizadjou, M., Kazemi-Talachi, A., Danesh-Manesh, H., Shakur-Shahabi, H., Janghorban, K. Investigation of Structure and Mechanical Properties of Multi-layered $\mathrm{Al} / \mathrm{Cu}$ Composite Produced by Accumulative Roll Bonding (ARB) process Composites Science and Technology 68 2008: pp. $2003-2009$.

http://dx.doi.org/10.1016/j.compscitech.2008.02.029 